\title{
EDUCATORS OPINION ON WEBINARS IN HIGHER EDUCATION
}

\author{
Andreas Ahrens \\ Hoschschule Wismar, Germany \\ Jelena Zascerinska \\ Centre for Education and Innovation Research, Latvia \\ Hariharan Ramar \\ Dr. Sivanthi Aditanar College of Education, India \\ Natalia Andreeva \\ Immanuel Kant Baltic Federal University, Russian Federation
}

\begin{abstract}
Three strategic priorities of the European Union such as Open Innovation, Open Science, and Openness to the World reveal that higher education focused on training of students as prospective specialists needed by society and production orient higher education how to change. In higher education the transition from distance learning to on-line learning has started. For on-line learning in higher education, webinars are becoming an indispensable tool. However, educators' opinion on webinars in higher education has not been analyzed. The aim of the present contribution is to analyze educators 'opinion on webinars in higher education underpinning elaboration of a hypothesis on use of webinars in on-line educational environment within higher education. The meaning of such key concepts as webinar, opinion, on-line learning and on-line educational environment is studied. Moreover, the study shows how the steps of the process are related: identifying webinars $\rightarrow$ defining educators' opinion $\rightarrow$ empirical study $\rightarrow$ conclusions. The empirical study was carried out in September 2015. The sample included 58 educators from the teacher training institution, namely Dr. Sivanthi Aditanar College of Education in India. The study results demonstrate that the educators' opinions on webinars in higher education are homogeneous. A hypothesis on use of webinars in on-line educational environment within higher education is elaborated. Directions of further research are proposed.
\end{abstract}

Keywords: competence, educators' opinion, experience, higher education, webinars.

\section{Introduction}

Modern European higher education is considered within three strategic priorities such as Open Innovation, Open Science and Openness to the World (Moedas, 2015) as shown in Figure 1.

These three strategic priorities such as Open Innovation, Open Science, and Openness to the World (Moedas, 2015) reveal that higher education focused on training of students as prospective specialists needed by society and production orient higher education how to change. In higher education the transition from 
distance learning to on-line learning has started. For on-line learning in higher education, webinars are becoming an indispensable tool. Webinars ensure online educational environment in higher education for closer inter-connections between students, educators, researchers and other participants in higher education as demonstrated in Figure 2.

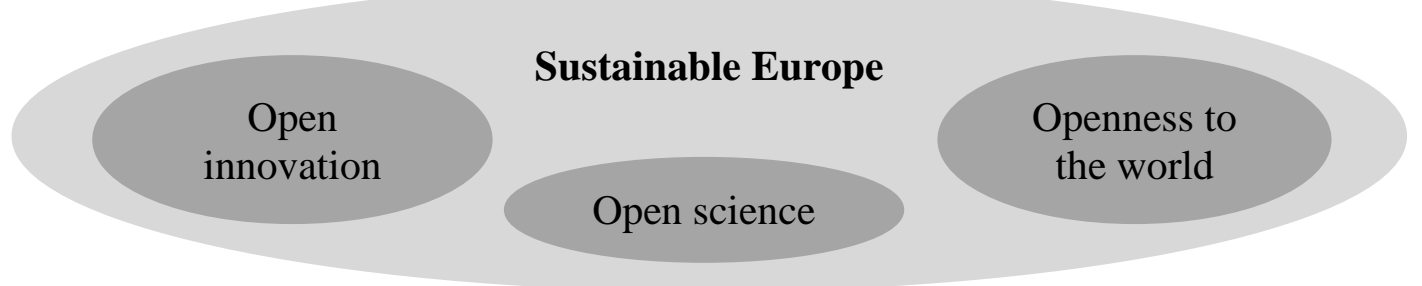

Figure 1 Three strategic priorities for sustainable European future

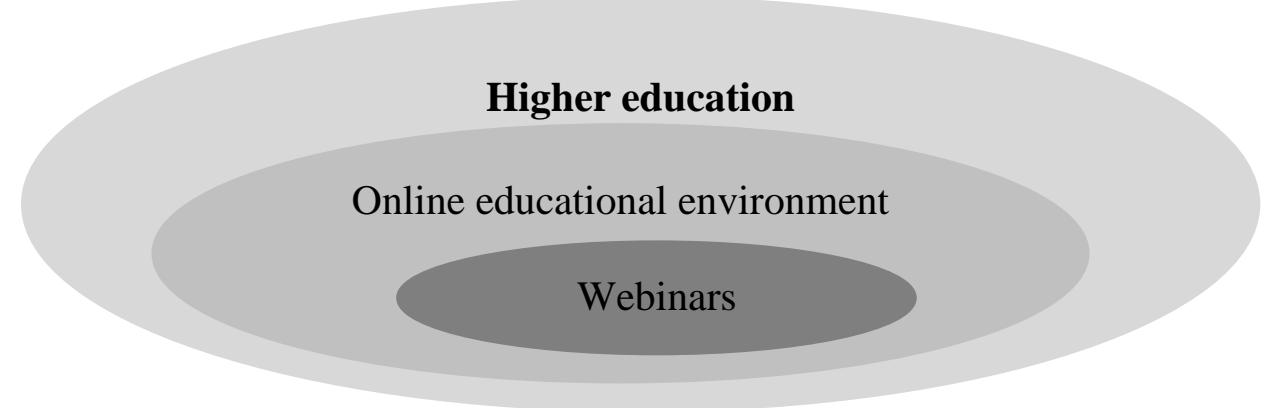

Figure 2 The relationship between higher education, online educational environment and webinars

Webinars are a tool for on-line learning within online educational environment in higher education. In comparison to distance learning which includes both types of learning, namely face-to-face as well as on-line, online learning proceeds in an online educational environment only.

Against this background, few studies investigate how webinar tools can facilitate interaction in online educational environment. Research on educators' experience in use of webinars has been carried out (Ahrens, Zaščerinska, Melnikova, Ramar, Clipa \& Andreeva, 2015). The other previous three studies analyzed the webinar delivery format in which the presenter and multiple participants from multiple sites interact with one another (Wang, Hsu, 2008):

1. Cheng, Ko, Kinshuk and Lin (2005) implemented a webinar system Anicam-Live at the Cyber University in Taiwan $(n=70)$ to facilitate synchronous communication (regarding instruction and office hours) between the instructor and the students. The results reveal that students were satisfied with the interactions among the instructor and 
2. students. The contribution did not discuss the instructor's webinar-use experiences.

3. $\mathrm{Ng}$ (2007) adopted a webinar system Interwise at the Open University of Hong Kong. He divided 200 students into 6 groups and had tutors deliver the course through both a face-to-face mode and a synchronous mode. The findings suggest that synchronous learning promotes tutor-student interaction better than student-student interaction.

4. Kohorst and Cox (2007) used a webinar system Elluminate to facilitate both virtual office hours and the communication of courserelated information to students. Elluminate effectively facilitated interaction between the instructor and individual students who had questions regarding the course materials.

Negative experiences in use of Elluminate to facilitate a seminar that connected two hospitals to each other (site vs. site) were found as Elluminate did not effectively promote the seminar owing to the content's irrelevance to participants' learning (de Gara \& Boora, 2006).

The perceptions of student-trainers who used webinar tools have been investigated (Wang \& Hsu, 2008) as well.

However, educators' opinion on webinars in higher education has not been analyzed.

The aim of the present contribution is to analyze educators' opinion on webinars in higher education underpinning elaboration of a hypothesis on use of webinars in higher education.

The meaning of such key concepts as webinar, opinion, on-line learning and on-line educational environment is studied. Moreover, the study demonstrates how the key concepts are related to the idea of higher education.

The methodological foundation of the present research is formed by the System-Constructivist Theory. The System-Constructivist Theory is based on (Maslo, 2006, 39)

- Parsons's system theory (Parsons, 1976) on any activity as a system,

- Luhmann's theory (Luhmann, 1988) on communication as a system,

- $\quad$ the theory of symbolic interactionalism (Mead, 1973) and

- $\quad$ the theory of subjectivism (Groeben, 1986).

The System-Constructivist Theory and, consequently, SystemConstructivist Approach to learning introduced by Reich (Reich, 2005) emphasizes that human being's point of view depends on the subjective aspect (Maslo, 2007, 39): experience plays the central role in the knowledge construction process (Maslo, 2007, 39). Therein, the subjective aspect of human being's point of view is applicable to the present research. 
Exploratory research was employed in the present research (Phillips, 2006). Exploratory research is aimed at developing hypotheses, which can be tested for generality in following empirical studies (Mayring, 2007). The exploratory methodology proceeds from exploration in Phase 1 through analysis in Phase 2 to hypothesis development in Phase 3 as illustrated in Figure 3.

Phase 1:

Exploration

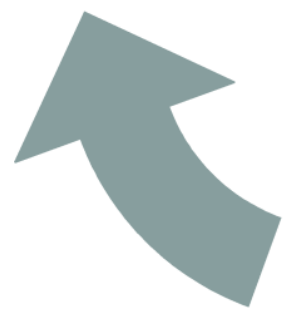

Phase 3:

Hypothesis Development
Phase 2:

Analysis

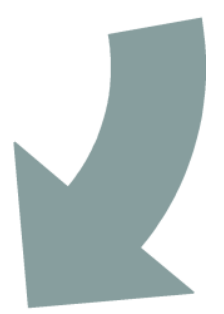

Figure 3 Methodology of the exploratory research

The remaining part of this contribution is organized as follows: the next section introduces the theoretical grounding on educators' opinion on webinars in higher education. The associated results of the empirical analysis will be presented in the following section. Finally, some concluding remarks are provided followed by a short outlook on interesting topics for further work.

\section{Theoretical Framework}

Webinar is a tool that provides computer mediated communication. In comparison to other computer mediated communication tools, webinar is able to transmit video, audio, and images, webinar also enables users to share applications and to use whiteboard, the objective being to exchange information in a real-time and two-way format (Wang \& Hsu, 2008). Webinar creates opportunities for both educators and learners to experience different levels of interaction online, and these opportunities are essentially different from other communication approaches such as discussion-board postings and e-mails (Wang \& Hsu, 2008). There are three formats for webinar-session delivery (Wang \& Hsu, 2008): 
(a) presenter vs. multiple participants from one site;

(b) presenter vs. multiple participants from multiple sites; and

(c) multiple participants from one site vs. multiple participants from one or multiple sites.

There are five advantages of using the webinar tool to facilitate communication between two sites (Wang \& Hsu, 2008):

(1) Webinar tool is affordable (de Gara \& Boora, 2006). Users can participate in a webinar session with a computer, video/audio capture devices, and broadband network connections.

(2) Webinar tool enables synchronous communication. Instructors can communicate with the learners in a synchronous format to provide immediate feedback to learners (Hotcomm, 2003).

(3) Webinar tool facilitates real-time multimedia demonstrations. Instructors can share the application on the presenter's site with all participants.

(4) Webinar tool facilitates multi-level interaction. Instructors can lecture, interact with the audience, facilitate participant group collaboration in a realtime format (Marjanovic, 1999), and designate certain participants to be in charge of the sessions.

(5) Webinar tool provides an environment in which participants can archive seminar content for personal review or for people who missed the real-time session.

Webinars are widely adopted as it can reduce corporations' travel expenses and travel time (Britt, 2006).

As webinar is relatively new for online educational environment in higher education, educators' opinion on webinars in higher education is of particular interest as educators play the key role in organizing on-line educational environment.

Opinion is initially determined as individual's view based on awareness and attitudes (Beļickis, Blūma, Koḳe, Markus, Skujiņa \& Šalme, 2000). Analysis of this definition allows identifying such a new definition of opinion as individual's view based on his/her knowledge, skills and attitudes to a phenomenon. This definition allows considering the terms opinion and view synonymously in the present research. As educators' opinion is based on educators' knowledge, skills and attitudes, educators' competence serves as an indicator of educators' opinion on webinars in higher education. Competence consists of knowledge, skills and attitudes as shown in Figure 4. The elements of competence, namely knowledge, skills and attitude, are inter-related (Ahrens \& Zaščerinska, 2015). Educators' negative attitude fails to promote the increase in the level of students' knowledge and skills as well as competence, in general (Ahrens \& Zaščerinska, 2015). In contrast, educators' positive attitude ensures the enrichment of the level of students' knowledge and skills as well as 
competence (Ahrens \& Zaščerinska, 2015). In turn, knowledge is presented by concepts (Žogla, 2001, 37). Skill is an ability to act in accordance with the required quality and volume (Bẹ̦ickis, Blūma, Koķe, Markus, Skujiṇa \& Šalme, 2000). Attitude is identified as an individual combination of evaluative judgments about a phenomenon (Ahrens \& Zaščerinska, 2015).

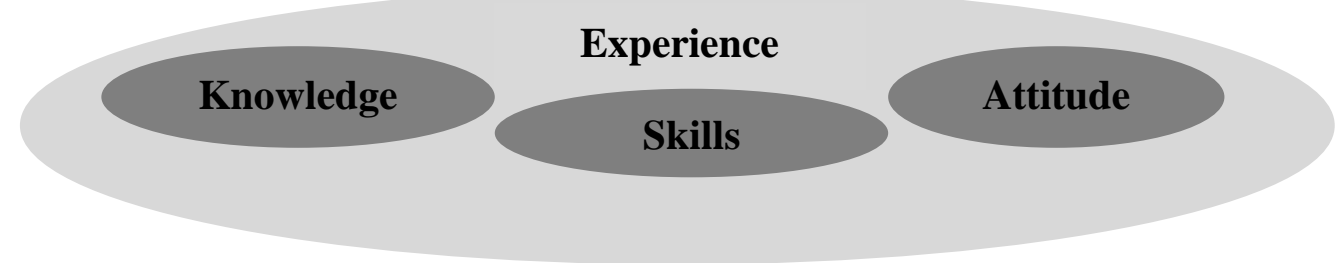

Figure 4 Elements of experience in pedagogy

In pedagogy the terms competence and experience are used synonymously (Ahrens \& Zaščerinska, 2015). As experience plays the central role in a knowledge construction process on webinars in higher education, the subjective aspect of human being's point of view is highlighted by the SystemConstructivist Theory.

\section{Empirical Results}

The present part of the contribution demonstrates the design of the empirical study, results of the empirical study and findings of the study.

The design of the empirical study comprises the purpose and question, sample and methodology of the present empirical study as depicted in Figure 5.

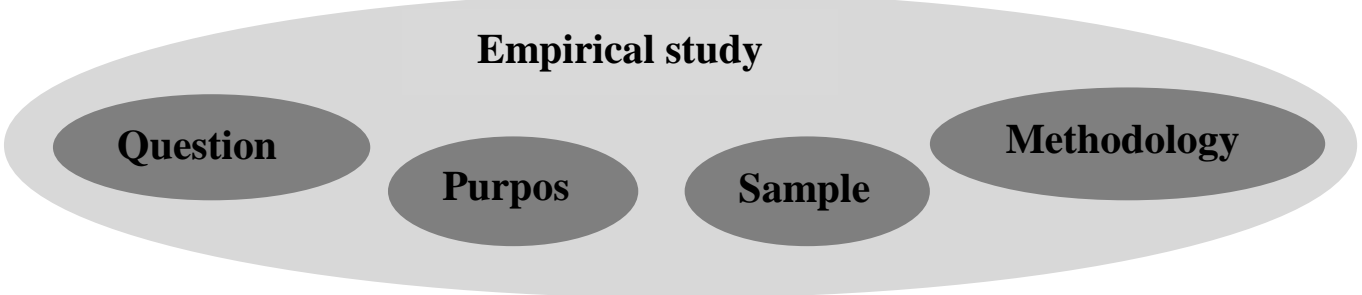

Figure 5 Elements of the design of the empirical study

The guiding research question is as follows: what is educators' opinion on webinars in higher education?

The aim of the empirical study is to analyze educators' opinion on webinars in higher education.

The present empirical study involved 58 teacher educators from Dr. Sivanthi Aditanar College of Education, Tiruchendur, Tamil Nadu, India, in September 2015. In the present contribution, the sample is considered homogeneous. 
The interpretive paradigm was used in the empirical study. The interpretive paradigm aims to understand other cultures, from the inside through the use of ethnographic methods such as informal interviewing and participant observation, and establishment of ethically sound relationships (Taylor \& Medina, 2013). The interpretative research paradigm corresponds to the nature of humanistic pedagogy (Lūka, 2008, 52). The interpretative paradigm creates an environment for the development of any individual and helps them to develop their potential (Lūka, 2008, 52). The core of this paradigm is human experience, people's mutual everyday interaction that tends to understand the subjectivity of human experience (Lūka, 2007, 104). The paradigm is aimed at understanding people's activity, how a certain activity is exposed in a certain environment, time, conditions, i.e., how it is exposed in a certain socio-cultural context (Lūka, 2007, 104). Thus, the interpretative paradigm is oriented towards one's conscious activity, and it is future-oriented (Lūka, 2007, 104). Interpretative paradigm is characterized by the researcher's practical interest in the research question (Cohen, Manion \& Morrison, 2003). The researcher is the interpreter.

In order to analyze the educators' opinion on webinars in higher education, the survey was based on the following questionnaire: Question 1: Do you know the concept of webinars? It should be noted that concepts present forms or levels of knowledge (Žogla, 2001, 37). Further on, knowledge is part of experience (Zaščerinska, 2013, 22). Question 2: Do you use webinars in higher education? The evaluation scale of five levels for Question 1 and 2 was given, namely, strongly disagree "1", disagree "2", neither disagree nor agree „3“, agree " 4 ", and strongly agree "5". Question 3: What is your attitude to webinars in higher education? The evaluation scale of five levels for Question 3 was given, namely, very negative "1", negative "2", neither negative nor positive ,3“, positive " 4 ", and very positive " 5 ". Both evaluation scales were transformed into the level system as illustrated in Table 1.

Table 1 Indicators and levels of educators' opinion on webinars in higher education

\begin{tabular}{|l|c|c|c|c|c|}
\hline \multirow{2}{*}{ Indicators } & \multicolumn{5}{|c|}{ Levels } \\
\cline { 2 - 6 } & Level 1 & Level 2 & Level 3 & Level 4 & Level 5 \\
\cline { 2 - 6 } & very low & low & average & optimal & high \\
\cline { 2 - 6 } & $\mathbf{1}$ & $\mathbf{2}$ & $\mathbf{3}$ & $\mathbf{4}$ & $\mathbf{5}$ \\
\hline $\begin{array}{l}\text { Educators' } \\
\text { knowledge and skills } \\
\text { in webinars in higher } \\
\text { education }\end{array}$ & $\begin{array}{l}\text { Strongly } \\
\text { disagree }\end{array}$ & Disagree & $\begin{array}{c}\text { Neither } \\
\text { disagree } \\
\text { nor agree }\end{array}$ & Agree & $\begin{array}{c}\text { Strongly } \\
\text { agree }\end{array}$ \\
$\begin{array}{l}\text { Educators' attitude to } \\
\text { webinars in higher } \\
\text { education }\end{array}$ & $\begin{array}{c}\text { Very } \\
\text { negative }\end{array}$ & Negative & $\begin{array}{c}\text { Neither } \\
\text { negative } \\
\text { nor } \\
\text { positive }\end{array}$ & Positive & $\begin{array}{c}\text { Very } \\
\text { positive }\end{array}$ \\
\hline
\end{tabular}


Question 4: What are advantages of webinars in higher education? Question 5: What are disadvantages of webinars in higher education? No evaluation scale was applied to Questions 4 and 5 as the questions were open.

The results of Question 1 (Knowledge), Question 2 (Skills) and Question 3 (Attitude) of the questionnaire used in the survey are demonstrated in Figure 6 where

- $\quad$ the vertical numbers show five levels to measure educators' opinion on webinars in higher education, and

- the horizontal numbers present the code number of the educator who participated in the survey.

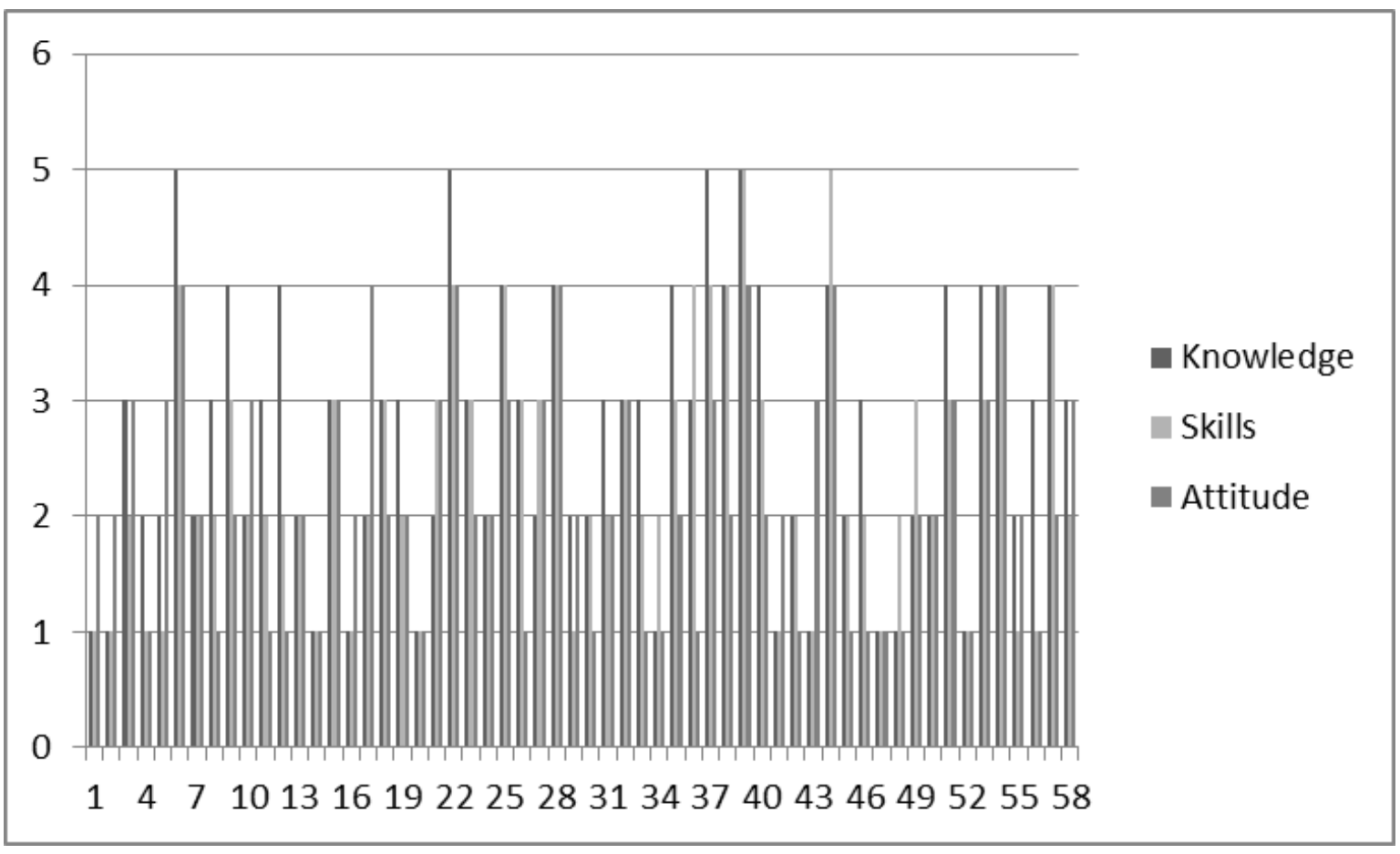

Figure 6 The results of Question 1 (Knowledge), Question 2 (Skills) and Question 3 (Attitude)

The results of Question 1 (Knowledge) of the questionnaire used in the survey show that

- one educator's evaluation of his/her knowledge of the concept of webinars refers to the very low level,

- 16 educators' evaluation of their knowledge of the concept of webinars refers to the low level,

- 16 educators' evaluation of their knowledge of the concept of webinars refers to the average level,

- 11 educators' evaluation of their knowledge of the concept of webinars refers to the optimal level, and 
- four educators' evaluation of their knowledge of the concept of webinars refers to the high level.

The results of Question 2 (Skills) reveal that

- 14 educators' evaluation of their skills in use of webinars in higher education refers to the very low level,

- 19 educators' evaluation of their skills in use of webinars in higher education refers to the low level,

- 13 educators' evaluation of their skills in use of webinars in higher education refers to the average level,

- 10 educators' evaluation of their skills in use of webinars in higher education refers to the optimal level, and

- two educators' evaluation of their skills in use of webinars in higher education refers to the high level.

The results of Question 3 (Attitude) demonstrate that

- 18 educators' evaluation of their attitude to webinars in higher education refers to the very low level,

- 20 educators' evaluation of their attitude to webinars in higher education refers to the low level,

- 13 educators' evaluation of their attitude to webinars in higher education refers to the average level,

- seven educators' evaluation of their attitude to webinars in higher education refers to the optimal level.

Question 4 (Advantages) includes such results as

- webinars ensure a better way of team teaching via the digital platform,

- webinars make available the content experts to get clarified about the subject taught,

- webinars increase the students' motivation as the content is new to them.

Question 5 (Disadvantages) discloses such results as

- it is costly to maintain and repair the functional units of the equipment,

- the need in sophisticated software systems to utilize the services of webinars which are not cost effective,

- the sound technical knowledge is essential to operate webinar services,

- rural areas remain without provision of the software needed for webinars.

The data were processed applying Excel software.

Frequencies of the educator' answers were determined in order to reveal educators' opinion on webinars in higher education as shown in Table 2. 
Andreas Ahrens, Jelena Zascerinska, Hariharan Ramar, Natalia Andreeva. Educators Opinion on Webinars in Higher Education

Table 2 Frequency of the educators' answers and mean of results

\begin{tabular}{|c|c|c|c|c|c|}
\hline Indicators & Levels & $\begin{array}{c}\text { Number of } \\
\text { answers }\end{array}$ & Percentage & $\begin{array}{c}\text { Indicators' } \\
\text { mean }\end{array}$ & $\begin{array}{l}\text { Total } \\
\text { mean }\end{array}$ \\
\hline \multirow{5}{*}{$\begin{array}{l}\text { Educators' } \\
\text { knowledge of the } \\
\text { concept of } \\
\text { webinars }\end{array}$} & Very low & 11 & $18.96 \%$ & \multirow{5}{*}{2.67} & \multirow{15}{*}{2.41} \\
\hline & Low & 16 & $27.58 \%$ & & \\
\hline & Average & 16 & $27.58 \%$ & & \\
\hline & Optimal & 11 & $18.96 \%$ & & \\
\hline & high & 4 & $6.89 \%$ & & \\
\hline \multirow{5}{*}{$\begin{array}{l}\text { Educators' skills of } \\
\text { use of webinars in } \\
\text { higher education }\end{array}$} & Very low & 14 & $24.13 \%$ & \multirow{5}{*}{2.43} & \\
\hline & Low & 19 & $32.75 \%$ & & \\
\hline & Average & 13 & $22.41 \%$ & & \\
\hline & Optimal & 10 & $17.24 \%$ & & \\
\hline & high & 2 & $3.44 \%$ & & \\
\hline \multirow{5}{*}{$\begin{array}{l}\text { Educators' attitude } \\
\text { to webinars in } \\
\text { higher education }\end{array}$} & Very low & 18 & $31.03 \%$ & \multirow{5}{*}{2.15} & \\
\hline & Low & 20 & $34.48 \%$ & & \\
\hline & Average & 13 & $22.41 \%$ & & \\
\hline & Optimal & 7 & $12.06 \%$ & & \\
\hline & High & 0 & $0 \%$ & & \\
\hline
\end{tabular}

The survey showed that the educators' knowledge of the concept of webinars $(27.58 \%)$, the educators' skills in webinars in higher education $(32.75 \%)$ as well as the educators' attitude to webinars in higher education $(34.48 \%)$ are of the low level. The findings of the empirical study allow concluding that the educators demonstrated a low level of competence in webinars in higher education (2.41). The summarizing content analysis (Mayring, 2004, 269) of the data reveals educators' opinion on webinars in higher education is homogeneous. The educators' opinion on webinars in higher education is found to be negative as the educators highlighted more disadvantages than advantages of webinars in higher education. The data analysis does not reveal educators' willingness and interest to use webinars in higher education.

\section{Conclusions}

The empirical findings of the research allow drawing the conclusions on educators' negative opinion on webinars in higher education.

The following hypothesis has been formulated: educators' competence in webinars in higher education enhances from a low level to a higher one if the course frame work is much focused towards

- $\quad$ provision of educators with a webinar tool,

- $\quad$ ensuring educators with technical support in use of webinars in higher education, 
- $\quad$ educator training in use of webinars in higher education.

The present research has limitations. The inter-connections between webinars, educators' opinion and higher education have been set. Another limitation is the empirical study conducted by involving the educators of one higher education institution only. Therein, the results of the study cannot be representative for the whole area. Nevertheless, the results of the research definition of educators' opinion - may be used as a basis of analysis of use of webinars in other higher education institutions. If the results of other institutions had been available for analysis, different results could have been attained. There is a possibility to continue the study.

Further research tends to focus on empirical studies to compare students and educators' opinions on webinars in higher education. The search for relevant methods for evaluation of use of webinars in higher education is proposed. And a comparative research of different countries could be carried out, too.

\section{References}

Ahrens, A., Zaščerinska, J., Melnikova, J., Ramar, H., Clipa, O., \& Andreeva, N. (2015). Use of Webinars in Higher Education: A Comparative Study of Educators' Experience. $3^{\text {rd }}$ Annual International Scientific-Practical Application Conference Trends in Science and Higher Education Studies Under Conditions of Globalization. Panevėžys College, Panevėžys, Lithuania. 22-23 October 2015.

Ahrens, A., \& Zaščerinska, J. (2015). A Comparative Study of Business and Engineering Students' Attitude to Mobile Technologies in Distance Learning. In: Patricia Ordonez De Pablos, Robert D. Tennyson and Miltiadis D. Lytras, Assessing the Role of Mobile Technologies and Distance Learning in Higher Education, Chapter 2 (pp. 29-59). IGIGlobal.

Beļickis, I., Blūma, D., Koķe, T., Markus, D., Skujiņa, V., (vad.) \& Šalme, A. (2000). Pedagogijas terminu skaidrojošā vārdnīca. Termini latviešu, anglu, vācu, krievu valodā. [Dictionary of Pedagogical Terms. Terns in Latvian, English, German, Russian].Rīga: "Zvaigzne ABC".

Britt, P. (2006). Seven reasons you need web conferencing. Network computing. Retrieved from http://www.networkcomputing.com/channels/networkinfrastructure/showArticle. jhtml?articleID=191600459.

Cheng, N. S., Ko, H. C., Kinshuk, \& Lin, T. (2005). A model for synchronous learning using the Internet. Innovations in Education and Teaching International, 42 (2), 2005, 181194.

Cohen, L., Manion, L., \& Morrison, K. (2007). Research Methods in Education. Routledge Education.

De Gara, C., \& Boora, R. (2006). Using Elluminate as a simple solution for telehealth initiatives for continuing medical education. In T. Reeves \& S. Yamashita (Eds.), Proceedings of world conference on e-learning in corporate, government, healthcare, and higher education 2006 (pp. 476-480). Chesapeake, VA: AACE, 2006, p. 476-480. 
Andreas Ahrens, Jelena Zascerinska, Hariharan Ramar, Natalia Andreeva. Educators Opinion on Webinars in Higher Education

Groeben, N. (1986). Handeln, Tun, Verhalten als Einheiten einer verstehend-erklärenden Psychologie. [Action, behavior as understanding units of an explanatory psychology]. Tübingen: Francke, 1986, 477 p.

Hotcomm, (2003). Synchronous tools and the emerging online learning model. http://hotcomm.com/tec/dlwp.pdf.

Kohorst, K., \& Cox, J. R. (2007). Virtual office hours using a tablet PC: E-lluminating biochemistry in an online environment. The International Union of Biochemistry and Molecular Biology, 35 (3), 2007, 193-197.

Luhman, N. (1988). Erkenntnis als Konstruktion. [Knowledge as a Construction]. Bern: Benteli, 1988, $14 \mathrm{p}$.

Luka, I. (2008). Students and the educator's co-operation as a means of development of students' ESP competence. Paper presented at the European Conference on Educational Research, University of Goteborg, 10-12 September 2008.

Luka, I., Ludborza, S., \& Maslo, I. (2009). Effectiveness of the use of more than two languages and quality assurance in European interuniversity master studies. Paper presented at the European Conference on Educational Research, University of Vienna, September 28-30, 2009.

Marjanovic, O. (1999). Learning and teaching in a synchronous collaborative environment. Journal of Computer Assisted Learning, 15, 1999, p. 129-138.

Maslo, E. (2007). Transformative Learning Space for Life-Long Foreign Languages Learning. In: International Nordic-Baltic Region Conference of FIPLV Innovations in Language Teaching and Learning in the Multicultural Context (pp. 38-46), 15-16 June 2007, Riga, Latvia, 2007.

Maslo, I. (2006). Skolotāju sociālintegrējošās darbības modelēšana. In: I. Maslo (Ed) No zināšanām uz kompetentu darbību (35.-44. Lpp). Latvijas Universitātes Akadēmiskais apgāds.

Mayring, P. (2004). Qualitative Content Analysis. In U. Flick, E. Von Kardoff \& I. Steinke (Eds), A Companion to Qualitative Research, (pp. 266-269). Glasgow, UK: SAGE.

Mayring, P. (2007). On Generalization in Qualitatively Oriented Research. Forum Qualitative Sozialforschung / Forum: Qualitative Social Research, 8 (3), Art. 26 (p. 1-8).

Mead, G. H. (1973). Geist, Identität, und Gesellschaft. Frankfurt: Suhrkamp, 1973, 298 p.

$\mathrm{Ng}$, K. C. (2007). Replacing face-to-face tutorials by synchronous online technologies: Challenges and pedagogical implications. International Review of Research in Open and Distance Learning, 8 (1). 2007. http://www.irrodl.org/index.php/irrodl/article/ view/335/776.

Parsons, T. (1976). Theorie sozialer Systeme. [Theory of Social System]. Opladen: Westdeutscher Verlag, 1976, pp. 9-30.

Phillips, D. (2006). Comparative Education: method. Research in Comparative and International Education, Volume 1, Number 4, 2006, 304-319.

Reich, K. Systemisch-konstruktivistische Pädagogik. [System Constructivist Pedagogy]. Weinheim:Beltz, 2005, 299 p.

Taylor, P. C., \& Medina, M. N. D. (2013). Educational Research Paradigms: From Positivism to Multiparadigmatic. The Journal of Meaning-Centered Education. 1.

Wang, Shiang-Kwei, \& Hsu, Hui-Yin. (2008). Use of the Webinar Tool (Elluminate) to Support Training: The Effects of Webinar-Learning Implementation from StudentTrainers' Perspective. Journal of Interactive Online Learning Volume 7, Number 3, Winter 2008, pp. 175-194. 
Zaščerinska, J. (2013). Development of Students' Communicative Competence within English for Academic Purposes Studies. Berlin, Germany: Mensch \& Buch. 2013.

Žogla, I. (2001). Mūsdienu mācību teorijas problēmas. [Problems of Modern Educational Theories]. Skolotājs Nr. 45/2001 (4.-7. lpp). Riga: RaKa. 